\title{
PREPARATION OF SILVICULTURAL PLANS IN PINUS SYLVESTRIS L. FORESTS: CASE STUDY OF OLTU PLANNING UNIT
}

\author{
GUNER, S. - YOLASIGMAZ, H. A.* \\ Faculty of Forestry, Artvin Coruh University, 08000 Artvin, Turkey \\ *Corresponding author \\ e-mail: hayolasigmaz@gmail.com; phone: +90-536-211-7300 \\ (Received $10^{\text {th }}$ Jan 2019; accepted $8^{\text {th }}$ Mar 2019)
}

\begin{abstract}
Forest resources in Turkey, according to the principles of ecosystem-based, multiple-use management approach, forest management chief/planning units are governed by forest management plans. Forest management planning process involves taking inventory, preparing the database with Geographic Information Systems (GIS), determining the forest management units and silvicultural treatments, and the preparation phase. After its completion begins the process of preparing silvicultural plans. First, in the regeneration areas, ecological conditions are evaluated and tree seeds are measured. Then regeneration methods are applied in this area and a detailed spatial and temporal planning is performed. Three different silvicultural plan tables are prepared by the forestry legislation. Beside the preparation of silvicultural plans, its enforcement has put an additional workload on forest management chief officers. Selected as a pilot region, the preparing of a silvicultural plan and monitoring its application with geographic database was undertaken at Oltu Forest Planning Unit. First of all, afforestation, regeneration and tending areas according to forest management plan were measured and evaluated. Then, the existing geographic database was updated to prepare the silvicultural plan. Then, in order to prepare and perform silvicultural prescriptions, spatial and temporal arrangements were added to the geodatabase. In the next step, the allowable cut was calculated. Finally, silvicultural treatments were applied at regeneration and tending areas, and illustrated with tables, graphs and maps. The paper is a case study for Oltu Forest Planning Unit, consisting mostly of Pinus sylvestris, while other tree species should be supported by a similar study in Turkey, particularly for mixed stands.
\end{abstract}

Keywords: silvicultural recipe, Pinus sylvestris L., geographic information systems, forest management plan, allowable cut

\section{Introduction}

Forest areas around the world are either decreasing or degrading structurally due to clearings for agriculture and residential development, road and energy line constructions, illegal logging and harmful forestry practices. Numerous plant and animal species living in these areas either become extinct or are under risk of extinction. Human population and demands are continuously increasing and becoming more varied. According to the Food and Agricultural Organization (FAO, 2015) data, global forest areas are 3.99 billion hectares (ha) in size and make up $30.6 \%$ of terrestrial lands. There has been a decrease of approximately six times the total forest area of Turkey (129 million ha) in global forest areas since 1990. As a result of the aforementioned reasons, utilization of forest resources is handled internationally and assessed globally with many conventions, primarily the Convention on Biodiversity. Sustainable management of forest resources takes form according to the criteria and indicators determined by the forestry philosophy of each country. Every country has made the required legal legislations and the technical and administrative infrastructure according to its own culture and economic structure (Yolasığmaz, 2013). 148 countries have 
policies that support sustainable forest management and 145 of them prepared forestry legislations based on these policies. 39\% of forest areas (2.1 billion ha) are managed by forest management plans (FAO, 2010; FAO, 2015; GDF, 2014a).

In Turkey, forest areas are administrated by the Ministry of Agriculture and Forestry. Forests are treated in two categories as protected and managed. Protected areas like national parks, nature reserve areas and nature parks are managed by Nature Conservation and National Parks General Directorate using long-term development plans and management plans. Management forest are managed by the General Directorate of Forestry at the scale of the administration chief offices/forest planning units, which are the smallest planning and administration units, using forest management plans prepared according to the principles of the ecosystem based multiple use forest management. Planning process consists of a) the inventory of forest ecosystem, b) setup of a geographic database using geographic information systems (GIS) technology, c) the generation of associated digital and baseline maps (stand map, forest function map, forest management units map etc.), d) the determination of management goals and conservation targets with a participatory approach by preparing forest management units map, e) the arrangement of utilization (i.e., determination of the location, time, quantity and the silvicultural treatments for the allowable cut), f) the presentation in plan format, (i.e., the preparation of cutting map and the associated tables, which are the final outputs) (GDF, 2017; Asan, 1999; Yolasığmaz, 2013; Başkent et al., 2008a, b, 2005; Asan, 1999).

The forestry philosophy in Turkey, in particular the planning approach and the basic principles need to be explained briefly to understand the topic better. $300 \mathrm{~m} \times 300 \mathrm{~m}$ plots are established within the planning unit using a systematic random sampling approach during forest inventory, which is the first phase of forest management plan preparation. The main goal of sampling is the generation of the baseline stand map. This map contains stands, compartments and sub-compartments. Compartments are those areas defined by natural lines like streams and artificial lines like roads and whose borders do not change. Sub-compartments are the sections of stands enclosed by compartments. Stand is a forest fragment that is greater than one hectare in size and differs from the adjacent forest areas by species, mixture, canopy closure and development stage. The main goal of forest area inventory and tree volume and increment inventory is to decide on stand symbols and to determine the stand borders and parameters. A stand symbol contains information like tree species, mixture, stand development stage and closure. Tree species are displayed by symbols. For example, species found at the study area including Pinus sylvestris, oak, poplar and juniper are displayed by the symbols Çs, M, Kv and Ar, respectively. The number of trees in the stand and stand volume are considered together to determine the tree species mixture type. The species that exceeds $10 \%$ of the stand values for these parameters are included in the stand symbol. The species that has the greatest number or volume by proportion is written first in the stand symbol. Stand development stages are symbolized by the letters $a$ (young stands: $<8 \mathrm{~cm} \mathrm{dbh),} b$ (pole pine stands: $8-19.9 \mathrm{~cm} \mathrm{dbh),} c$ (pre-mature stands: $20-35.9 \mathrm{~cm} \mathrm{dbh}), d$ (mature stands: $36-51.9 \mathrm{~cm} \mathrm{dbh}$ ) and $e$ (old stands: $>52 \mathrm{~cm}$ dbh). Crown closure, or canopy closure (B (degraded); 1-10\% crown cover, $1 ; 11-40 \%$ crown cover, $2 ; 41-70 \%$ crown cover, $3 ; 71-100 \%$ crown cover) is defined as the sheltering or shadowing of the ground by tree crowns (GDF, 2017). Development stages and crown closure are two important parameters because the former one is used to 
determine the method of silvicultural treatment to be applied in the stand and the latter is used to decide on the quantity and the intensity of the allowable cut.

Silvicultural treatments are grouped under four headings including afforestation, tending, regeneration and rehabilitation (Saatçioğlu, 1971; Genc, 2017; GDF, 2017, 2014b). The type and method of the silvicultural treatment and the allowable cut are decided based on factors like ecological and growth conditions of the forest area, biological requirements of tree species, road network, transport and management opportunities, technical capacities of forest enterprises, management goals, conservation targets, forest types and stand parameters. While the silvicultural treatment is applied to the entire sub-compartment, the sub-compartment is/can be partitioned at fields where only afforestation is carried out (Eraslan, 1982). Afforestation areas are the gaps in the forest regime that are to be planted with trees within the plan period. Regeneration areas are those fields which are either done or about to be finished with their management periods and either will be regenerated or their regeneration has begun in the previous period and is still going on. Tending areas are the forested areas except afforestation and regeneration areas. These fields undergo silvicultural treatments in accordance with management goals and conservation targets according to primarily species and then stand canopy closure, development stage, and whether it's a pure or mixed stand. Tending treatments including weeding, release cutting and weeding and thinning are proposed for young, pole pine and pre-mature and old stands, respectively. The silvicultural method used in thinning is low cutting and it is considered heavy and moderate based on the dose or the amount of the treatment. In regeneration areas, final yield allowable cut is taken while in tending areas, intermediate yield allowable cut is taken. Afforestation, regeneration and tending areas are shown by different colors according to the pertinent legislation in harvest maps, which are the final output of forest management plans (Saatçioğlu, 1971; Genç, 2001; GDF, 2017, 2014b; Yolasığmaz and Güner, 2016).

The dominant species at the study is the Pinus sylvestris, which is a light tree. It is not damaged by frost. It has tap root system and grows fast in youth stage. Therefore, the weeding period in Pinus sylvestris forests is either one or two years. Pole pine stand stage lasts about eight to ten years. The initial thinnings in premature stand stage are heavy low cuttings. The subsequent thinnings that take place every ten years are moderate low cuttings. Tending treatments like the weak low thinnings are performed towards the end of management period past 70 years of stand age. Regeneration is carried out in closed stands with gaps where there are no sufficient seed trees based on slope. Uniform clear cutting method is performed in areas where there is no danger of erosion whereas planting under the forest canopy method is employed in the areas where there is risk of erosion. Uniform shelterwood method, which is based on natural regeneration, is preferred in Pinus sylvestris stands where there is sufficient quantity of seed trees. Preparation cuts generally are not needed in the regeneration practices performed using the uniform shelterwood method. Abundant seed years occur every two to four years. Difficulty in determining the abundant seed year of Pinus sylvestris is not encountered because its seeds mature over three years. A light cutting after two to three years following the seed cutting done in the abundant seed year and a subsequent removal cutting two to three years later must be performed as the seedlings grow fast. Weeding must be carried out at least once after the removal cutting to reduce the competition of seedlings with the dense live cover present at the areas. 
In Turkey, preparation of silvicultural plans, which are the application bases of forest management plans, has been incorporated in the planning process as a legal necessity within the last decade. However, standards for the preparation and application stages of the silvicultural plans could not be established completely. Moreover, silvicultural plans are prepared by conducting a series of field and office work in addition to the ones done for forest management plans with the technical support of administration of chief officers and other administrators.

The type of the silvicultural treatments, the decided functional allowable cut and the sub-compartments in which the silvicultural treatment will take place are identified in two different tables for the regeneration/afforestation and tending areas in the forest management plans. The silvicultural treatment times to be carried out in these areas involve ten or twenty year periods depending on the plan execution schedule. However, the exact location of treatment in each year and the types of regeneration and tending methods to be applied are not clearly stated (GDF, 2017, 2014b).

Three additional tables are prepared as part of the silvicultural plan preparation according to the pertinent legal notice. The first of these tables indicates the field studies that need to be carried out during the preparation of the silvicultural plan, the second one identifies the treatment methods to be applied to the regeneration and tending areas and the third one provides information on the years of the silvicultural treatments and the allowable cut (GDF, 2014b).

Besides, spatial databases generated using GIS technology are designed to prepare forest management plans and maps and thus they are not suited for preparing silvicultural plans and associated maps. The monitoring of structural changes in the forest also is not suited to the monitoring and control of the silvicultural treatments (Yolasığmaz and Keleş, 2009).

The main aim of this study is to prepare a silviculture plan of Oltu Forest Planning Unit dominated by Pinus sylvestris. In addition, the database prepared using GIS is to measure the success of silvicultural treatments and to monitor forests.

\section{Materials and methods}

\section{Materials}

The main materials used in the study are the forest management plan attribute and digital data of the Oltu Forest Planning Unit and the geographic database. The measurements and examinations in the study area especially were focused on afforestation and regeneration areas where soil analyses data, ecological conditions, current stand structures and abundant seed years were assessed and determined.

\section{Study area}

The study area is enclosed by $714000-777000$ ( $\left.30^{\circ} 41^{\prime} 08^{\prime \prime} 42^{\prime \prime}-40^{\circ} 39^{\prime} 45^{\prime \prime}\right)$ east longitudes and 4470000-4510000 (40 32' 46" - 40 46' 51") north latitudes in zone 37 according to UTM coordinate system and ED 50 datum (Fig. 1 and 2). The planning unit is bordered by Narman Forest Planning Unit to the southeast, Tortum Forest Planning Unit to the southwest, Hisar Forest Planning Unit to the northeast Kilıçkaya Forest Forest Planning Unit in the Yusufeli Forest Enterprise to the northwest. Oltu Forest Planning Unit is within the boundary of Oltu Forest Enterprise with a distance of 100 to $180 \mathrm{~km}$ to Erzurum province. Elevation ranges from 1105 to $3045 \mathrm{~m}$. Average 
temperature is $9.8^{\circ} \mathrm{C}$ and the annual precipitation is $393.3 \mathrm{~mm}$ according to meteorological data. High slope topography and harsh winter conditions render living conditions difficult resulting in accelerating migration from the area to urban regions (GDF, 2015a).
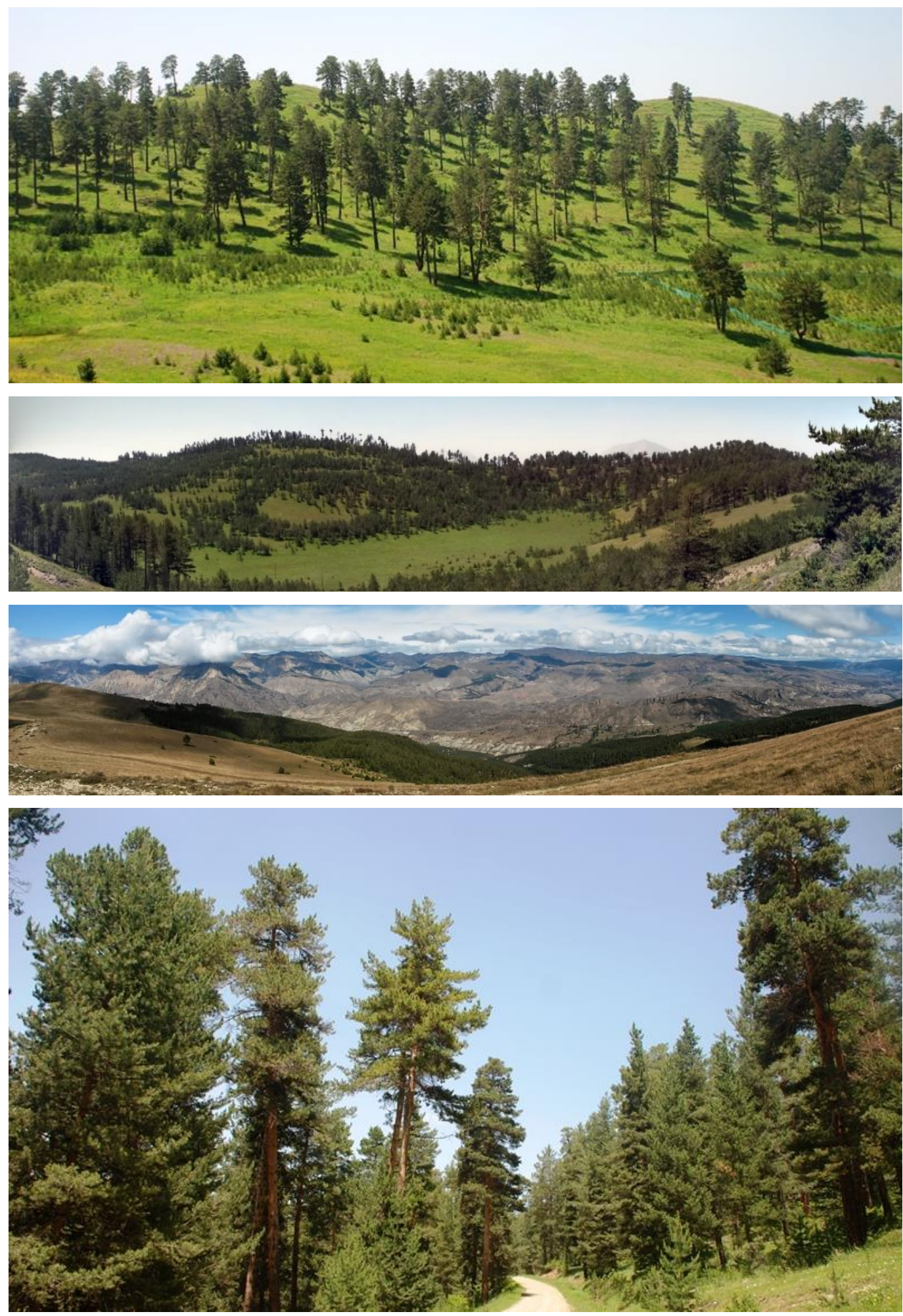

Figure 1. Images of the study area 


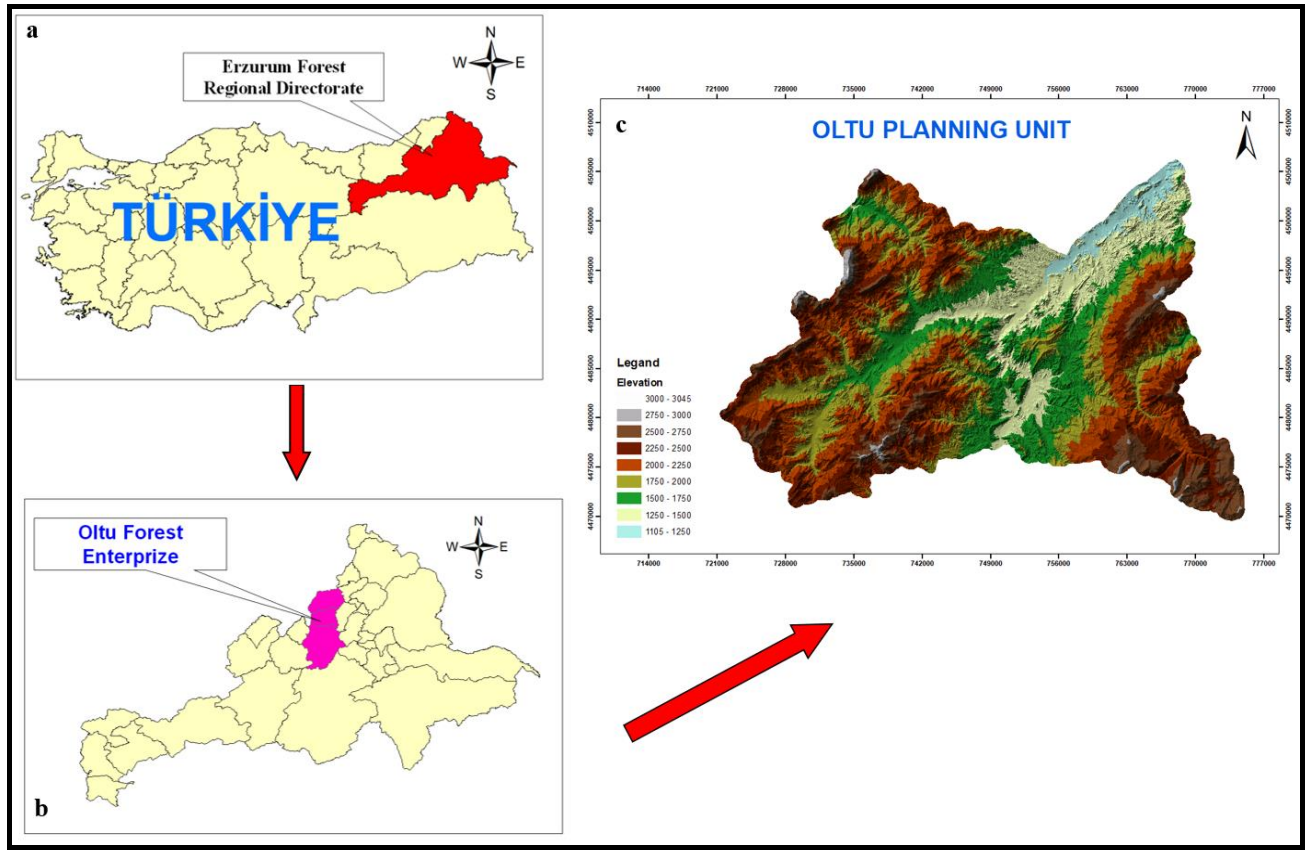

Figure 2. Location of the study area according to the administrative organization of Turkish forests. a) Location of Erzurum Forest Regional Directorate within Turkey, b) location of Oltu Forest Enterprise within Erzurum Forest Regional Directorate, and c) elevation map of Oltu Forest Planning Unit

The total area of the study area is 105108.707 ha of which 28788.303 ha is forested and 13755.785 ha is non-forest area. The planning unit is comprised of 586 compartments and 2679 sub-compartments with 43 different stand types identified (GDF, 2015a).

The dominant species of the flora include Pinus sylvestris (L.), Juniperus sp., Qercus sp. and Populus tremula (L.). Even though a comprehensive plant sociology study is not conducted at the study area, four different tree species (Platanus orientalis, Acer sp., Pyruselae agnifoliave, Sorbus torminalis) that do not form stands by themselves but are part of the mixture either individually or in groups were recorded in the forest management plan. Additionally, four different small trees and shrub forms and nine plant species were identified and also recorded in the forest management plan. The management units used for wood production are dominated by Pinus sylvestris (L.). There are also poplar (Populus tremula (L.)) stands with normal canopy closure. Forest areas where Pinus sylvestris, juniper and poplar codominated and formed mixtures together were identified in degraded areas.

Oltu Forest Planning Unit is grouped into eight different forest management units according to the forest management plan (Table 1). $17.455 \%$ of the study area is planned to be utilized for economic purposes while $53.061 \%$ is planned for ecological use and the remaining $29.485 \%$ is planned for socio-cultural use.

\section{Methods}

\section{Field measurements and assessments}

Investigations were done in afforestation and regeneration areas in the summer months of 2015. Data related to ecological conditions (slope, aspect, elevation, soil 
type, soil depth and stoniness, etc.) were collected and current stand structure was inspected in area. Abundant seed years and presence or absence of seed trees were determined in order to decide on the regeneration method.

Table 1. Area distribution of the forest management unit in Oltu Planning Unit (GDF, 2015a)

\begin{tabular}{c|c|c}
\hline Forest management units & Area (ha) & \% \\
\hline A-Wood Production & 18346.336 & 17.455 \\
B-Nature Conservation & 37767.906 & 35.932 \\
C-Wildlife Development Areas & 5353.919 & 5.094 \\
D- High Mountain Forest Ecosystem & 11244.117 & 10.698 \\
E- Forest Ecosystem Monitoring Areas & 43.090 & 0.041 \\
F- Erosion Control - Soil Conservation & 1362.304 & 1.296 \\
G- Conservation of Water Sources & 30748.068 & 29.254 \\
H- Recreation & 242.969 & 0.231 \\
\hline Total & $\mathbf{1 0 5 1 0 8 . 7 0 7}$ & $\mathbf{1 0 0 . 0 0 0}$ \\
\hline \multicolumn{2}{c}{}
\end{tabular}

\section{Design and configuration of database}

The baseline map used for the preparation of silvicultural plans is the forest management plan geographic database. The primary dataset within the database associated with compartments, sub-compartments, stand parameters like stand type information, age class and site quality class and forest management units and harvest map were used directly. Data including the volume of trees per hectare $\left(\mathrm{m}^{3} / \mathrm{ha}\right)$, annual tree volume increment $\left(\mathrm{m}^{3} / \mathrm{ha} /\right.$ year), types of silvicultural treatments as defined in the plan (afforestation, regeneration and tending) and the decided functional allowable cuts/tending allowable cuts $\left(\mathrm{m}^{3}\right)$ were entered in the geographic database of the silvicultural plan in addition to the forest management plan data. Also, data titles displaying the fundamental components of a silvicultural plan like the silvicultural treatment method, five different types of silvicultural treatments, five different silvicultural treatment times, the quantity of the allowable cuts decided for each treatment, the number of treatments and the realized allowable cut were added as columns to the database.

\section{Preparation of silvicultural recipes}

Afforestation areas are gaps in the forest and degraded forest areas that are suitable for afforestation. Silvicultural recipe to be applied to the gaps and degraded forest areas (Tables 2 and 3).

Table 2. The silvicultural recipe to be applied to gaps

\begin{tabular}{c|c}
\hline Silvicultural treatment number & Silvicultural recipe \\
\hline Silvicultural Treatment_1 & Planting \\
Silvicultural Treatment_2 & Weeding (1 year after planting) \\
Silvicultural Treatment_3 & Weeding (2 years after planting) \\
Silvicultural Treatment_4 & Release cutting (10 years after second weeding) \\
\hline
\end{tabular}


Table 3. The silvicultural recipe to be applied to degraded forest areas

\begin{tabular}{c|c}
\hline Silvicultural treatment number & Silvicultural recipe \\
\hline Silvicultural Treatment_1 & Clear cutting+Planting \\
Silvicultural Treatment_2 & Weeding (1 year after planting) \\
Silvicultural Treatment_3 & Weeding (2 years after planting) \\
Silvicultural Treatment_4 & Release cutting (10 years after second weeding) \\
\hline
\end{tabular}

Regeneration areas are those stands in which regeneration treatments started in the previous plan period and are ongoing or they either completed their management plan cycle or are in the process of completion. Factors like the technical capacity of the forest enterprise, workforce and road condition beside growth environment characteristics like elevation, slope, soil properties (soil type, stoniness, soil depth, etc.) and stand parameters such as the biological requirements of the tree species, canopy closure and mixture patterns were considered during the silvicultural treatments to be applied to these areas. Regeneration areas were divided into three groups as follows "areas currently undergoing regeneration", "Pinus sylvestris stands with canopy closure level 1" and "Pinus sylvestris stands with canopy closure levels 2 and 3" (Tables 4, 5 and 6 ).

Table 4. Silvicultural recipe to be applied to stands that currently are undergoing regeneration (Çsd1/Çsa0)

\begin{tabular}{c|c}
\hline Silvicultural treatment number & Silvicultural recipe \\
\hline Silvicultural Treatment_1 & Removal cutting (in 2015 or 2016 years) \\
Silvicultural Treatment_2 & Weeding (1 year after removal cutting) \\
Silvicultural Treatment_3 & Release cutting (10 years after second weeding) \\
\hline
\end{tabular}

Table 5. Silvicultural recipe to be applied to Pinus sylvestris stands with canopy closure level 1 (Çsd1)

\begin{tabular}{c|c}
\hline Silvicultural treatment number & Silvicultural recipe \\
\hline Silvicultural Treatment_1 & Clear cutting + planting or planting under the forest canopy \\
Silvicultural Treatment_2 & Removal cutting (3 years after the planting) \\
Silvicultural Treatment_3 & Weeding (1 year after removal cutting) \\
Silvicultural Treatment_4 & Release cutting (10 years after second weeding) \\
\hline
\end{tabular}

Table 6. Silvicultural recipe to be applied to Pinus sylvestris stands with canopy closure levels 2 and 3 (Çsd2/ Çsd3)

\begin{tabular}{c|c}
\hline Silvicultural treatment number & Silvicultural recipe \\
\hline Silvicultural Treatment_1 & Seed cutting (abundant seed year) \\
Silvicultural Treatment_2 & Light cutting (3 years after seed cutting) \\
Silvicultural Treatment_3 & Removal cutting (2 or 3 years after light cutting) \\
Silvicultural Treatment_4 & Weeding (1 year after removal cutting) \\
Silvicultural Treatment_5 & Release cutting (10 years after second weeding) \\
\hline
\end{tabular}


Tending is proposed to all forest areas except afforestation and regeneration areas. Factors like the technical capacity of the forest enterprise, sociocultural and socioeconomic structure of the villages within and adjacent to the forest, workforce potentials of these villages, social problems and disputes and road condition were considered during the spatial arrangement of the tending areas. Tending cuts every ten years are proposed during a management period of twenty years due to the biological requirements of Pinus sylvestris species. Low cutting method is used in Pinus sylvestris forests primarily even though the silvicultural treatment method varies based on the development stages of stands. Allowable cut during tending is calculated following the inventory conducted in the field and it is determined based on the forest function that the area provides, management goals and conservation targets. The current characteristics of the stands, (i.e., stand parameters including canopy closure and stand development stage) affect the dose and method of the silvicultural treatment to be applied to these areas. The silvicultural treatment methods to be applied to each stand type in tending areas are shown in Table 7.

Table 7. Silvicultural treatment methods to be applied to tending areas

\begin{tabular}{|c|c|c|c|}
\hline Stand symbol & $\begin{array}{l}\text { Silvicultural } \\
\text { treatment }-1\end{array}$ & Stand symbol & $\begin{array}{l}\text { Silvicultural } \\
\text { treatment }-2\end{array}$ \\
\hline Çsa0, ÇsYaa0, CvBma0 & Weeding & Çsa0, ÇsYaa0, CvBma0 & $\begin{array}{c}\text { Release cutting (Heavy } \\
\text { low thinning) }\end{array}$ \\
\hline Çsa & Weeding & Çsa & $\begin{array}{c}\text { Release cutting (Heavy } \\
\text { low thinning) }\end{array}$ \\
\hline Çsab1, Çsab2 & $\begin{array}{l}\text { Release cutting (Heavy } \\
\text { low thinning) }\end{array}$ & \multirow{3}{*}{$\begin{array}{l}\text { Çsab2, Çsb3, Çsbc2, Çsbc3, } \\
\text { Çsc2, Çsc3, Çscd2, Çscd3, } \\
\text { Çsd3, ÇsKvbc2, ÇsKvbc3, } \\
\text { Kvb2, Kvbc2, Kvbc3, } \\
\text { KvÇsbc2, KvÇsbc3 }\end{array}$} & \multirow{3}{*}{ Moderate low thinning } \\
\hline $\begin{array}{l}\text { Çsb3, Çsbc3, ÇsMbc3, } \\
\text { Kvb3, Kvbc3, KvÇsbc3 }\end{array}$ & Heavy low thinning & & \\
\hline $\begin{array}{c}\text { Çsab2, Çsbc2, Çsc2, Çsc3, } \\
\text { Çscd2, Çscd3, Çsd3, } \\
\text { ÇsKvbc2, ÇsKvbc3, } \\
\text { Kvb2, Kvbc2, KvÇsbc2 }\end{array}$ & Moderate low thinning & & \\
\hline $\begin{array}{c}\text { Çsbc1, Çsc1, Çscd1, } \\
\text { Kvb1, Kvbc1 }\end{array}$ & Weak low thinning & $\begin{array}{l}\text { Çsab1, Çsbc1, Çsc1, Çscd1, } \\
\text { Çsd1, Kvb1, Kvbc1 }\end{array}$ & Weak low thinning \\
\hline
\end{tabular}

Tending areas are divided into ten tending blocks in traditional planning. Here, each tending block was further grouped into ten separate sub-tending blocks, which is different from the traditional approach. Since the legislation requires that the harvest jobs be given to the local residents in the nearest settlement, spatial planning was carried out to provide employment to each village every year.

\section{Calculation of the allowable cuts}

Intermediate yield allowable cut (the allowable cut taken from tending areas)

Ten separate tending blocks were established and each tending block was further grouped into ten separate sub-tending blocks and numbered. The treatment years for the sub-blocks within each tending block were determined according to their ordinal hierarchy such that the first set of treatments would be completed between 2015 and 
2024 and the second set of treatments would be completed between 2025 and 2034 across the tending blocks.

Final yield allowable cut (the allowable cut taken from regeneration areas)

The entire volume within regeneration areas will be harvested during the 20 year plan period but in different years. Once the youth is established healthily, the trees in the canopy will be harvested by removal cutting. The remaining trees will increase their volume during the period between seed cutting and removal cutting. Therefore, half of the tree volume increment was added to the current tree volume in calculations of the allowable cut in regeneration areas. The allowable cuts that will take place in these areas based on the silvicultural treatment method and the cutting technique were calculated/determined as follows:

- In degraded Pinus sylvestris stands (BÇs), the entire volume will be harvested by clear cutting in the first treatment and seedlings will be planted.

- In Pinus sylvestris stands with level 1 canopy closure (Çscd1) where planting under the forest canopy will take place, it is assumed that $20 \%$ of the current tree volume will be harvested during the initial treatment, $50 \%$ of the remaining tree volume will be harvested during the second treatment, i.e., the light cutting, and that $97 \%$ of the remaining tree volume will be harvested by the next treatment, which is the removal cutting.

- In Pinus sylvestris stands with level 1 canopy closure (Çscd1) where uniform clear cutting will take place, it is assumed that $97 \%$ of the tree volume will be clear cut during the initial treatment and the area will be replaced by seedlings.

- In Pinus sylvestris stands with level 2 canopy closure (Çscd2) where uniform shelterwood method will be applied, it is proposed that $20 \%$ of the current tree volume will be harvested during seed cutting, which is the initial treatment, $50 \%$ of the remaining tree volume will be taken during light cutting, which is the second treatment and that $96 \%$ of the remaining tree volume will be taken during removal cutting.

- In Pinus sylvestris stands with level 2 canopy closure (Çscd2) where uniform clear cutting will take place, it is assumed that $97 \%$ of the tree volume will be clear cut during the initial treatment and the area will be replaced by seedlings.

- In Pinus sylvestris stands with level 2 canopy closure (Çscd2) where planting under the forest canopy will take place, it is assumed that $20 \%$ of the current tree volume will be harvested during the initial treatment, $50 \%$ of the remaining tree volume will be harvested during the second treatment, i.e., the light cutting, and that $97 \%$ of the remaining tree volume will be harvested by the next treatment, which is the removal cutting.

- In Pinus sylvestris stands with level 3 canopy closure (Çscd3), it is assumed that uniform shelterwood method will be applied and $40 \%$ of the current tree volume will be harvested during initial treatment, $50 \%$ of the remaining tree volume will be taken during light cutting, which is the second treatment and that $96 \%$ of the remaining tree volume will be taken during removal cutting.

- In stands currently undergoing regeneration where light cutting is recommended, it is proposed that $50 \%$ of the current tree volume will be harvested and that $96 \%$ of the remaining tree volume will be taken during removal cutting. If light cutting is not recommended at these areas, than it is 
proposed that $96 \%$ of the tree volume at the area will be harvested by removal cutting.

- It is proposed that 3-4\% of tree volume will be left at regeneration stands as value trees for ecological and biological balance.

\section{Results and discussion}

According to the forest management plan data, the total tree volume at the planning unit is $1415343.798 \mathrm{~m}^{3}$, annual tree volume increment is $44214.787 \mathrm{~m}^{3} /$ year and the amount of agreed allowable cut during the plan period of 20 years is $1121891.449 \mathrm{~m}^{3}$ (Table 8; Fig. 3).

Table 8. The distribution area of the silvicultural treatments by type and other areas according to the forest management plan

\begin{tabular}{c|c|c}
\hline Silvicultural treatment & Area (ha) & \% \\
\hline Afforestation & 1.981 & 0.002 \\
Regeneration & 121.933 & 0.116 \\
Tending & 11646.306 & 11.080 \\
No treatment & 79514.118 & 75.649 \\
Other forest areas & 74.439 & 0.071 \\
Agricultural area & 12673.448 & 12.057 \\
Residential areas & 1076.484 & 1.024 \\
\hline Total & $\mathbf{1 0 5 1 0 8 . 7 0 7}$ & $\mathbf{1 0 0 . 0 0 0}$ \\
\hline
\end{tabular}

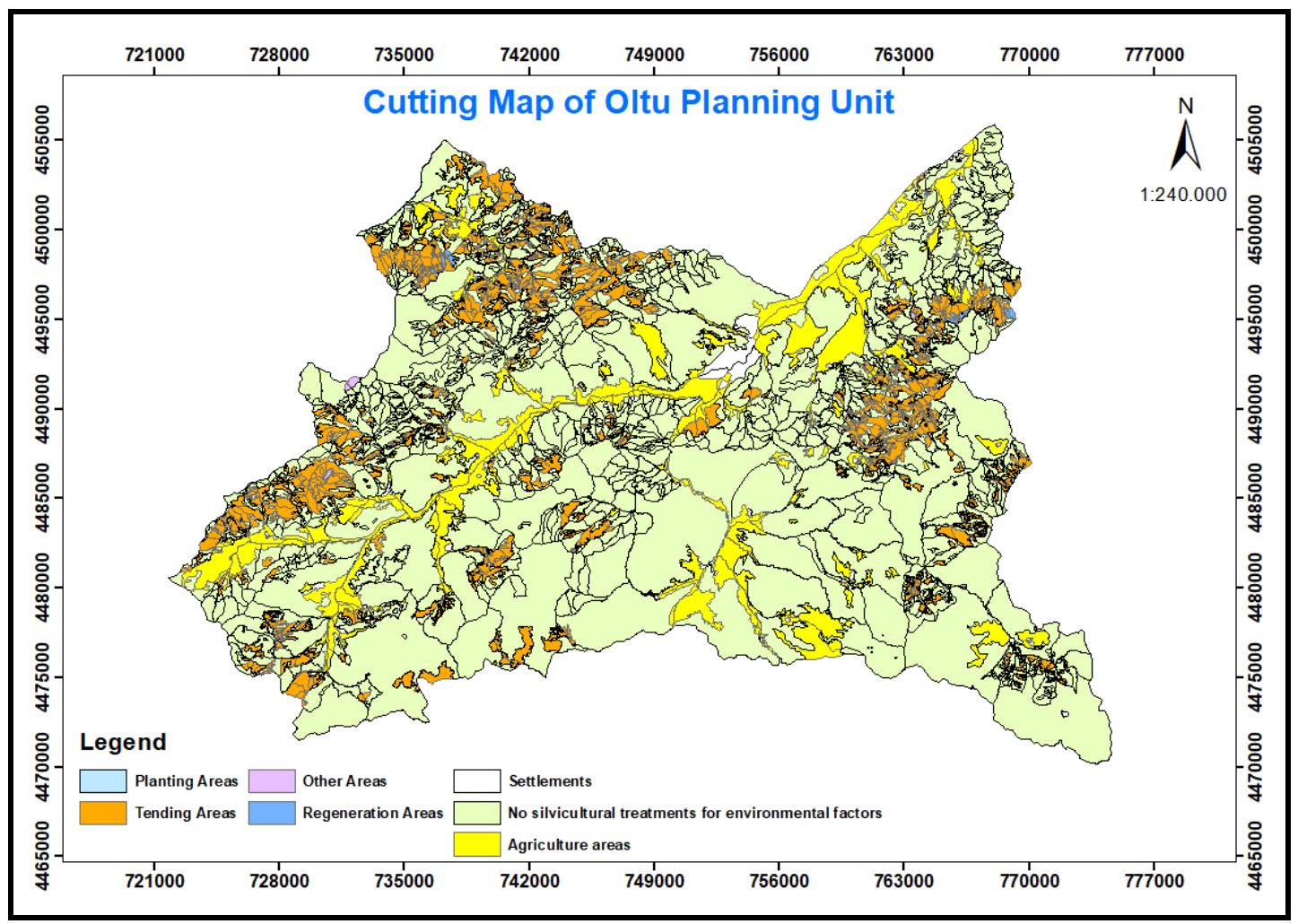

Figure 3. Cutting map of Oltu Planning Unit according to forest management plan 
In the silvicultural plan, thinning and release cutting are proposed as the first treatments at tending areas. Thinning and release cutting are planned for $81.262 \%$ and $17.685 \%$ of the tending areas, respectively (Table 9; Fig. 4).

Table 9. The distribution of the area and allowable cut by silvicultural treatment method in silvicultural plan

\begin{tabular}{c|c|c|c|c}
\hline Silvicultural method & Area (ha) & $\mathbf{\%}$ & Allowable cut $\left.\mathbf{( m}^{\mathbf{3}}\right)$ & $\mathbf{\%}$ \\
\hline Afforestation areas & $\mathbf{1 . 9 8 1}$ & 0.017 & - & - \\
Planting & 1.981 & 0.017 & - & - \\
Tending areas & $\mathbf{1 1 6 4 6 . 3 0 6}$ & 98.947 & $\mathbf{9 7 9 7 4 . 4 1 8}$ & 87.671 \\
Thinning & 9564.720 & 81.262 & 97974.418 & 87.671 \\
Release & 2081.586 & 17.685 & - & - \\
Regeneration areas & $\mathbf{1 2 1 . 9 3 3}$ & 1.036 & $\mathbf{1 3 7 7 7 . 4 8 3}$ & 12.329 \\
Natural regeneration_Uniform shelterwood & 35.275 & 0.300 & 4114.895 & 3.682 \\
Natural regeneration_Uniform clear cutting & 12.149 & 0.103 & 97.190 & 0.087 \\
Artificial regeneration_Planting under the forest & $\mathbf{7 4 . 5 0 9}$ & 0.633 & 9565.397 & 8.559 \\
canopy & $\mathbf{1 1 7 7 0 . 2 1 9}$ & 100.000 & $\mathbf{1 1 1 7 5 1 . 9 0 1}$ & 100.000 \\
\hline Sum & & &
\end{tabular}

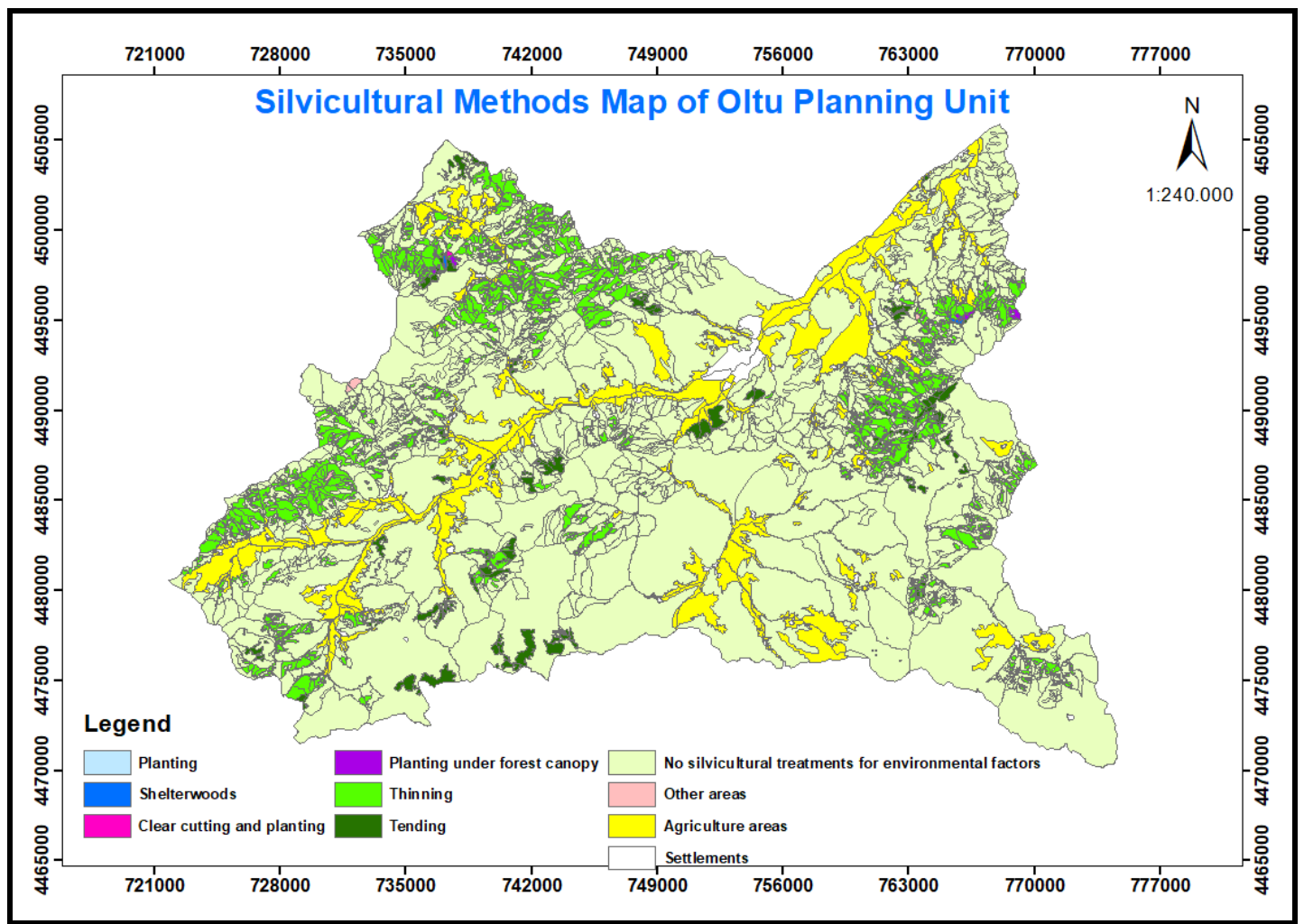

Figure 4. Silvicultural methods map of Oltu Planning Unit

$112189.449 \mathrm{~m}^{3}$ of allowable cut is proposed according to the forest management plan while $111751.901 \mathrm{~m}^{3}$ is proposed in the silvicultural plan. $437.547 \mathrm{~m}^{3}$ of allowable cut 
was abandoned, which consisted of the value trees left at the area to allow for the sustenance of wildlife.

Abundant seed year occurs every two years and the first abundant seed year was 2015. Therefore, regeneration started in the abundant seed year of 2017. The focus was on completing the ongoing regeneration practices in the planning unit.

We tried to keep the size of the tending areas even across the years, where the average annual size and the average tending allowable cut quantity were $1186.702 \mathrm{ha} /$ year and $4898.721 \mathrm{~m}^{3} /$ year, respectively. The total quantity of the allowable cut of the tending areas is $97974.418 \mathrm{~m}^{3}$ and makes up $87.671 \%$ of the total allowable cut whereas the allowable cut that will be harvested from the regeneration areas constitutes $12.329 \%$ of the total allowable cut. We aimed to keep the annual treatment area size and the quantity of the annual allowable cut equal during the treatments to be applied to the regeneration areas.

The average annual treatment area size and the average quantity of the annual allowable cut to be conducted in the regeneration areas were planned as 21.774 ha/year and $688.874 \mathrm{~m}^{3} /$ year, respectively. The average annual treatment area size and the average annual allowable cut quantity were 1186.702 ha and $5587.595 \mathrm{~m}^{3} /$ year, respectively when the allowable cut and treatment area size were examined across the years and regeneration and afforestation areas were combined (Table 10; Fig. 5).

Table 10. Silvicultural treatments areas and the allowable cut distributions according to the treatments years

\begin{tabular}{|c|c|c|c|c|c|c|c|}
\hline \multirow{2}{*}{$\begin{array}{l}\text { Treatment } \\
\text { year }\end{array}$} & \multirow{2}{*}{$\begin{array}{c}\text { Afforestation } \\
\text { Area (ha) }\end{array}$} & \multicolumn{2}{|c|}{ Tending } & \multicolumn{2}{|c|}{ Regeneration } & \multirow{2}{*}{$\begin{array}{c}\text { Total } \\
\text { treatment } \\
\text { area (ha) } \\
\end{array}$} & \multirow{2}{*}{$\begin{array}{c}\text { Total } \\
\text { allowable } \\
\text { cut }\left(\mathbf{m}^{3}\right)\end{array}$} \\
\hline & & Area (ha) & $\begin{array}{c}\text { Allowable } \\
\text { cut }\left(\mathbf{m}^{3}\right)\end{array}$ & Area (ha) & $\begin{array}{c}\text { Allowable } \\
\text { cut }\left(\mathbf{m}^{3}\right)\end{array}$ & & \\
\hline 2015 & - & 1150.529 & 5958.670 & - & - & 1150.529 & 5958.670 \\
\hline 2016 & - & 1194.489 & 4921.596 & - & - & 1194.489 & 4921.596 \\
\hline 2017 & - & 1154.303 & 4083.296 & 17.591 & 368.882 & 1171.894 & 4452.178 \\
\hline 2018 & - & 1167.978 & 4946.626 & 19.462 & 1572.548 & 1187.440 & 6519.174 \\
\hline 2019 & - & 1147.563 & 3898.569 & 62.432 & 859.504 & 1209.995 & 4758.073 \\
\hline 2020 & - & 1177.190 & 5072.762 & 47.712 & 1360.985 & 1224.902 & 6433.747 \\
\hline 2021 & - & 1178.904 & 6264.392 & 5.209 & - & 1184.113 & 6264.392 \\
\hline 2022 & - & 1162.920 & 4371.161 & 19.045 & 2343.676 & 1181.965 & 6714.837 \\
\hline 2023 & - & 1108.471 & 5129.365 & 53.203 & 3507.587 & 1161.674 & 8636.952 \\
\hline 2024 & - & 1203.958 & 4340.771 & 34.158 & - & 1238.116 & 4340.771 \\
\hline 2025 & 1.981 & 1150.529 & 5958.670 & 27.368 & - & 1179.877 & 5958.670 \\
\hline 2026 & 1.981 & 1194.489 & 4921.596 & - & - & 1196.470 & 4921.596 \\
\hline 2027 & - & 1154.303 & 4083.296 & - & - & 1154.303 & 4083.296 \\
\hline 2028 & - & 1167.978 & 4946.626 & 28.480 & 3764.301 & 1196.458 & 8710.927 \\
\hline 2029 & 1.981 & 1147.563 & 3898.569 & 45.718 & - & 1195.262 & 3898.569 \\
\hline 2030 & - & 1177.190 & 5072.762 & 16.691 & - & 1193.881 & 5072.762 \\
\hline 2031 & - & 1178.904 & 6264.392 & 5.209 & - & 1184.113 & 6264.392 \\
\hline 2032 & - & 1162.920 & 4371.161 & - & - & 1162.920 & 4371.161 \\
\hline 2033 & - & 1108.471 & 5129.365 & 19.045 & - & 1127.516 & 5129.365 \\
\hline 2034 & - & 1203.958 & 4340.771 & 34.158 & - & 1238.116 & 4340.771 \\
\hline Sum & 5.942 & - & 97974.418 & - & 13777.483 & - & 111751.901 \\
\hline
\end{tabular}




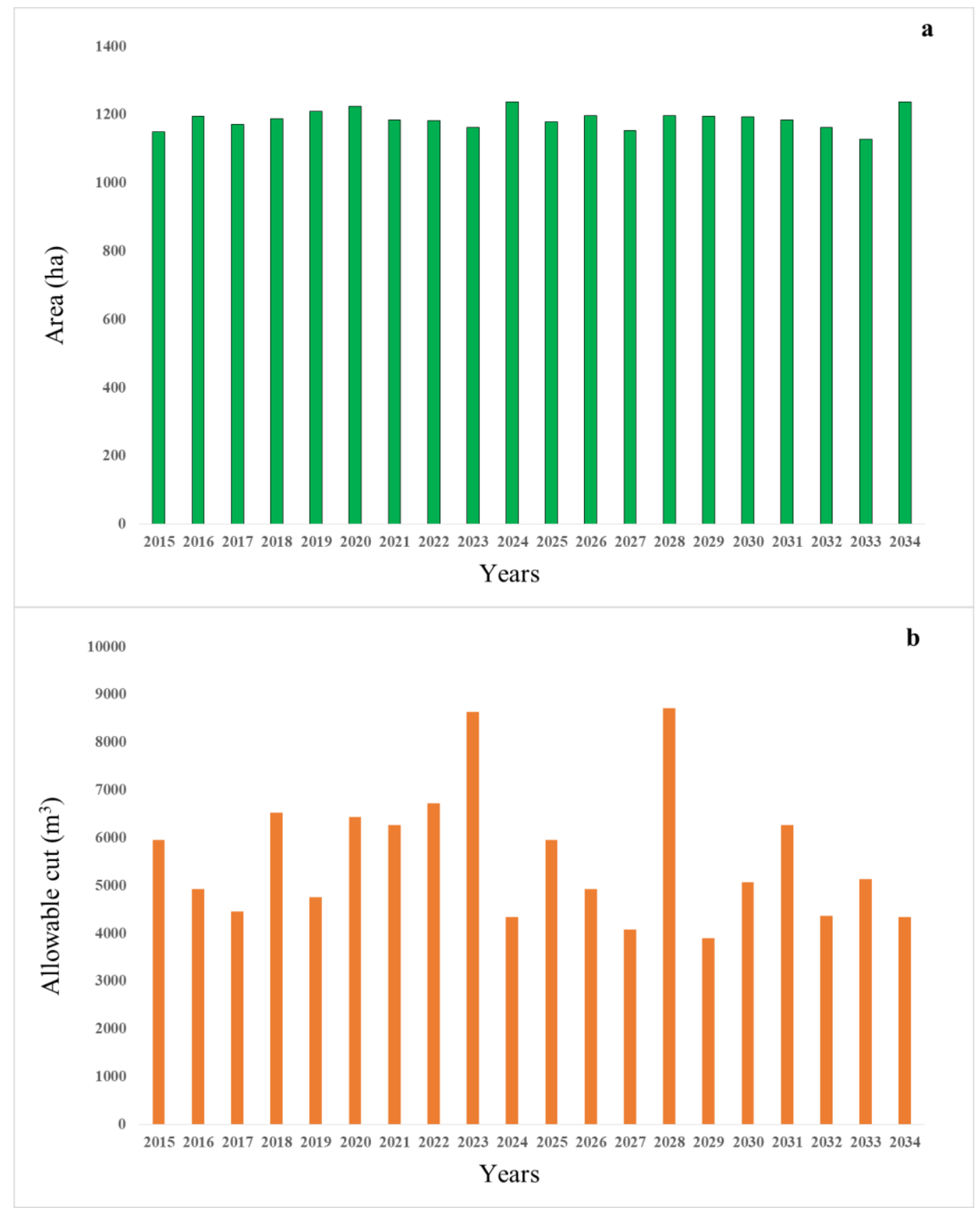

Figure 5. The distribution of total treatment area (a) and allowable cut (b) according to treatment years

\section{Conclusion}

The silvicultural plan of Oltu Forest Planning Unit was prepared using the joint approaches of forest management and silviculture disciplines. A new spatial database was designed in the silvicultural plan by using the treatment areas in the forest management plan and the associated geographic database as the base. Silvicultural recipes were prepared according to the silvicultural treatment type (afforestation, regeneration and tending) for each sub-compartment. Final outputs in the form of harvest maps or in other words, silvicultural plan map was produced and provided to the users. 
General assessments like the silvicultural treatment methods to be applied at the study area, their distribution across the years and the number of treatments were performed and provided as outputs of this study using the analysis, query and presentation capabilities of GIS. In addition to these outputs, other outputs including detailed silvicultural plan tables, numerous analyses on stand parameters like development stage, age and site quality classes as well as the treatment areas and the application years for the five separate treatment types can be generated and provided.

Overall, 1.98 ha area was agreed to be afforested, 11646.306 ha was decided to undergo tending cuts and 121.933 ha area was decided to be regenerated in the forest management plan of Oltu Forest Planning Unit. The forest management plan was adhered to in the silvicultural plan and thus there was no change in these areas. Total of $111751.901 \mathrm{~m}^{3}$ allowable cut was planned at the study area during the 20 year plan period, comprised of $97974.418 \mathrm{~m}^{3}$ intermediate yield allowable cut and $13777.483 \mathrm{~m}^{3}$ final yield allowable cut.

The annual tree volume increment is $44214.786 \mathrm{~m}^{3} /$ year and approximately $12.64 \%$ of the annual increment will be harvested as the allowable cut every year. This is much lower than the national average annual allowable cut to annual tree volume increment ratio of $39.87 \%$ (GDF, 2015b). As stated earlier quantitatively, large portion of Oltu Forest Planning Unit is utilized for ecologic and social goals. Similarly, the demand for wood production in the US decreased, as opposed to increasing demand for ecological and social services (D'Amato et al., 2017). As a result, silvicultural practices and planning approaches in Turkey are developing within the framework of ecological and social objectives.

The silvicultural plan was prepared for Oltu region forests, which are composed of pure Pinus sylvestris stands generally dominated by one species and specifically for Oltu Forest Planning Unit. Different tree species, different species compositions and different forestry problems exist in different regions of Turkey because of the geographic diversity of the country. The number of silvicultural treatments, their years and the quantity of the allowable cut also will differ in these regions. Therefore, similar studies need to be conducted in different forest regions of Turkey, in which silvicultural plans and digital baselines should be generated for each forest planning unit.

Acknowledgements. This study was carried out as part of the project 2016. F10.02.02 supported by the Scientific Research Projects Coordinatorship of Artvin Çoruh University (AÇÜBAP). Foremost, we thank (AÇÜBAP) for the support they provided. Also, we extend our thanks to the Anatolia Environment Forestry Mapping Inc. Company (ANÇEO), the General Directorate of Forestry and the Faculty of Forestry of Artvin Çoruh University for all the support and help they provided during the preparation of the silvicultural plan and the forest management plan and for the acquisition of the data.

\section{REFERENCES}

[1] Asan, Ü. (1999): Multiple use of forest resources and planning systems. - Proceedings of Meeting on the Multiple Use Forest Management Planning, Bolu, Turkey, 5-6 May, pp. 33-40.

[2] Baskent, E. Z., Kose, S., Keles, S. (2005): Forest management planning system of Turkey: constructive criticism towards the sustainable management of forest ecosystems. - International Forestry Review 7(3): 208-217. 
[3] Baskent, E. Z., Baskaya, S., Terzioglu, S. (2008b): Developing and implementing participatory and ecosystem based multiple use forest management planning approach (ETÇAP): Yalnızçam case study - Forest Ecology and Management 256(4): 798-807.

[4] Baskent, E. Z., Terzioglu, S., Baskaya, S. (2008a): Developing and implementing multiple-use forest management planning in Turkey. - Environmental Management 42: 37-48.

[5] D'Amato, A. W., Jokela, E. J., O'Hara, K. L., Long, J. N. (2017): Silviculture in the United States: An amazing period of change over the past 30 years. - Journal of Forestry 116(1): 55-67.

[6] Duan, K., Sun, G., Sun, S., Caldwell, P. V., Cohen, E. C., McNulty, S. G., Zhang, Y. (2016): Divergence of ecosystem services in US National Forests and Grasslands under a changing climate. - Scientific Reports 6: 24441.

[7] Eraslan, İ. (1982): Forest Management, Istanbul University. - Forth Press, İstanbul.

[8] FAO (2010): Global Forest Resources Assessment 2010 Main Report. FAO Forestry Paper 163. - Food and Agriculture Organization of the United Nations, Rome.

[9] FAO (2015): Global Forest Resources Assessment 2015. How Are the World's Forests Changing? - Food and Agriculture Organization of The United Nations, Rome.

[10] Genc, M. (2017): Forest Tending. - Süleyman Demirel Univ. Isparta.

[11] GDF (2014a): Forest Inventory Results. - Republic of Turkey Ministry of Forestry and Water Affairs General Directorate of Forestry, Forest Management and Planning Department, Ankara.

[12] GDF (2014b): Technical Principal of Silviculture Applications. - Republic of Turkey Ministry of Forestry and Water Affairs General Directorate of Forestry Directorate of Silviculture, Notification Nu: 298, January, Ankara.

[13] GDF (2015a): Oltu Forest Management Plan. - General Directorate of Forestry, Ankara, Turkey.

[14] GDF (2015b): Turkey Forest Wealth. - Republic of Turkey Ministry of Forestry and Water Affairs General Directorate of Forestry, Ankara.

[15] GDF (2017): Preparation of Technical Principal of Forest Management Plan in Turkey. Notification Num: 299, Republic of Turkey Ministry of Forestry and Water Affairs General Directorate of Forestry Directorate of Silviculture, Ankara.

[16] Saatçioğlu, F. (1971): Silvicultural Methods. - Istanbul University, 1648/172, Istanbul, Turkey.

[17] Yolasığmaz, H. A. (2013): Forestry in Turkey from the Forest Management Perspective. - International Caucasian Forestry Symposium, Symposium Proceeding, 24-26 October, 2013, Artvin, Turkey, pp. 299-301.

[18] Yolasığmaz, H. A., Keleş, S. (2009): Data base design with GIS in ecosystem based multiple use forest management in Artvin, Turkey: a case study in Balc1. - Forest Management Planning Unit Sensors 9: 1644-1661.

[19] Yolasığmaz, H. A., Guner, S. (2016): The process of silviculture planning in Turkey: Hisar case study. - Šumarski List 140(9-10): 503-514. 